\title{
Unravelling historical cost developments of offshore wind energy in Europe
}

\author{
J.A. Voormolen, H.M. Junginger, W.G.J.H.M. van Sark* \\ Utrecht University, Copernicus Institute of Sustainable Development, Heidelberglaan 2, 3584 CS Utrecht, The Netherlands
}

\section{H I G H L I G H T S}

- New insights in cost developments of offshore wind energy in Europe.

- Increase of CAPEX is linked to distance to shore and depth.

- Increase of CAPEX partly due to limited competition in turbine market.

- Levelized cost of electricity increases from $120 € /$ MWh in 2000 towards $190 € / M W h$ in 2014.

\section{A R T I C L E I N F O}

\section{Article history:}

Received 30 June 2015

Received in revised form

15 October 2015

Accepted 29 October 2015

\section{Keywords:}

Cost development

Offshore wind

Learning

Levelized cost of electricity

\begin{abstract}
A B S T R A C T
This paper aims to provide insights in the cost developments of offshore wind energy in Europe. This is done by analysing 46 operational offshore wind farms commissioned after 2000. An increase of the Capital Expenditures (CAPEX) is found that is linked to the distance to shore and depth of more recent wind farms and commodity prices. Analysis results indicate that these two factors are only responsible for about half of the observed CAPEX increase, suggesting other factors such as turbine market with limited competition also led to an increasing CAPEX. Using CAPEX, Annual Energy Production, Financings costs and Operational Expenditures, the development of average Levelized Cost of Electricity (LCoE) is shown to increase from $120 € /$ MWh in 2000 towards $190 € / M W h$ in 2014, which is a direct result of the CAPEX increase. The results indicate very different LCoE values among European countries, from currently about 100 Euro/MWh in Denmark and Sweden to 150-220 Euro/MWh in all other countries investigated suggesting an effect of national policy frameworks on the LCoE of offshore wind energy.
\end{abstract}

(c) 2015 Elsevier Ltd. All rights reserved.

\section{Introduction}

With the growing awareness of human induced climate change, countries are investing in renewable energy sources. As a result, renewable energy technologies are rapidly developing. Most of these technologies are relatively young and have not been in a commercial stage for more than 20 years. One of these technologies is offshore wind energy, which is currently mainly located in the North West of Europe. At the end of 2014, 2488 offshore wind turbines were installed with a combined total of $8.045 \mathrm{GW}$ installed capacity (EWEA, 2015). At the beginning of 2015, 11 Offshore Wind Farms (OWFs) are under construction with a capacity of $2.9 \mathrm{GW}$. Most recent scenarios predict an installed capacity in 2020 of 23.5 GW in Europe (EWEA, 2014). Beyond 2020,

\footnotetext{
* Corresponding author.

E-mail addresses: jasper.voormolen@hotmail.com (J.A. Voormolen), h.m.junginger@uu.nl (H.M. Junginger), w.g.j.h.m.vansark@uu.nl (W.G.J.H.M. van Sark).
}

offshore wind is expected to continue its rapid expansion, as it will also be implemented outside Europe. China has a target to install $50 \mathrm{GW}$ of offshore wind by 2030 (GWEC, 2014).

Although the future of offshore wind looks promising the Levelized Cost of Energy (LCoE) of offshore wind ranged between 114 and $190 € / M W h$ in Germany in 2013, compared to 70 and $85 € /$ MWh respectively for coal and gas fired power plants (Fraunhofer ISE, 2013). In general, all renewable technologies are or have been more expensive compared to conventional energy producing technologies because of their lack of maturity and market size. Due to the high LCoE, offshore wind presently is not profitable without financial support from governments (IEA, 2014). However, governments are not expected to continue supporting offshore wind energy and therefore the industry needs to reduce the LCoE rapidly (Perveen et al., 2014; European Wind Energy Technology Platform, 2014).

In 2012, the potential cost reduction of offshore wind energy in the United Kingdom was studied from an engineering perspective. A potential LCoE reduction of 39\% from 2011 to 2020 was reported 
(The Crown Estate, 2012). A similar study was done a year later in Germany, reporting a LCoE reduction potential between 32\% and 39\% in 2023 compared to 2013 (Fichter and Prognos, 2013). In 2011, the Dutch government made an agreement with the Dutch offshore wind sector that the LCoE needs to be reduced with $40 \%$ by 2020 , in order to receive long-term support (Rijksoverheid, 2011). Based on these sources it appears that there is general consensus within the offshore wind sector that a $40 \%$ cost reduction within 10 years seems realistic. Also scientific literature has studied future developments in offshore wind energy (Junginger et al., 2005; Van der Zwaan et al., 2012). As installed capacity increases, experience and efficiency of the supply chain increase resulting in lower production costs. This phenomenon is captured by the experience curve: it has been empirically shown for many products that for each doubling of the total capacity the production costs decrease with a fixed percentage, called the learning rate (Junginger et al., 2010). In 2005, Junginger et al. reported progress ratios of $77-85 \%$ for offshore wind. This implied that offshore wind has the potential to become an affordable renewable technology, if deployed at large scale.

Despite the optimistic forecasts for the future cost developments, the Capital Expenditures (CAPEX) have actually increased since 2000 (NREL, 2010). It increased from 1.5 M€/MW in 2000 to 4.0 M€/MW in 2010 and it was expected to remain above $4.0 \mathrm{M}$ $€ / M W$ up to 2015. This increase suggests that an experience curve approach cannot be applied in a straightforward fashion for offshore wind farms (MacGillivray et al., 2014; Möller et al., 2012). Frequent arguments explaining the CAPEX increase are increasing commodity prices and OWFs being built further offshore in deeper waters (UKERC, 2010; Rabobank, 2011; IRENA, 2012; Kaiser and Snyder, 2010). Additionally bottlenecks in the supply of turbines and specialized installation vessels led to price increases. However, the influence of these factors so far has not been quantified in relation to the CAPEX increase. In 2015, IRENA published a cost analysis of renewable energy costs in which it reconstructed the LCoE development of offshore wind. The results indicate an increase from around $100 \$ / \mathrm{MWh}$ in 2000 to $200 \$ / \mathrm{MWh}$ in 2014, but also with a large variance in specific years. No additional analysis was performed in order to be able to explain these developments. Also, there is no data on how the LCoE differs between different sites or countries, although this has been studied for onshore wind energy (Klaassen et al., 2005; EWEA, 2011a). Another issue when analysing the costs of offshore wind is that there is a mismatch between the use of CAPEX and LCoE. The CAPEX development is used to present existing OWFs, while the LCoE is used to predict future costs. Due to the limited number of offshore wind farms that have been built, until a few years ago, the amount of data on CAPEX, LCoE and financial data was not sufficient to perform such research.

The aim of this research is to provide better insight in the recent CAPEX increase and to connect the historical CAPEX and LCoE developments. This is done by analysing offshore wind farms in Europe that became fully operational between 2000 and January 2015. The scope of this research is limited to European OWFs after 2000 , as OWFs built before 2000 were much more similar to onshore technology and cannot be compared with current offshore technology.

Therefore the research question in this paper is: How did the capital expenditures and the levelised cost of electricity of offshore wind farms in Europe develop since 2000? Additional sub questions are: Can the influence of depth, distance to shore and commodity prices be excluded from the capital expenditures? Have costs developed differently among certain countries?

Section 2 present a short background on learning. In Section 3 the research methodology is presented. Results of the analyses of the influence of location and commodity prices on the CAPEX development are given and discussed in Section 4, followed by how important input factors for the LCoE have developed and how the LCoE developed as a result. Additionally it is analysed if costs developed differently among countries. Section 5 closes the paper with a conclusion and policy implications as well as recommendations for further research.

\section{Background}

\subsection{Experience curves}

It was made clear in the introduction that a (one factor) experience curve cannot be used to explain the historical developments of the CAPEX of offshore wind energy. First of all, the learning curve is about one specific product while each offshore wind farm is a combination of many custom-made products and services (and thus as done by Junginger et al. (2005), one would have to devise experience curves per component). Secondly it does not account for different costs based on geographical characteristics, therefore, it does not consider the difference between an OWF installed $10 \mathrm{~km}$ from shore at $10 \mathrm{~m}$ depth or $50 \mathrm{~km}$ and $40 \mathrm{~m}$ depth. Although the experience curve does not apply to offshore wind energy, it can still be expected that the costs go down. Several factors that can lead to cost reductions (Junginger et al. 2010), are:

- Learning-by-doing,

- Learning-by-using,

- Learning-by-search,

- Standardization of the production,

- Redesigning and upsizing of the product.

These factors have been used to identify technological learning within offshore wind energy. Another important aspect is that the experience curve describes production costs, while only prices are published and there is no information related to the profit margins available. The dynamics between costs and prices is described for an emerging product/technology by Boston Consulting Group (1968) (see Fig. 1). During the development phase it is possible that the costs are actually higher than the price. As experience is gained by increasing the cumulative output, costs start to decrease while the price remains constant and the producer will start to make a profit. As increasing experience will continue to lead to lower production costs, new market entrants are attracted by the increasing profit margins. Increasing competition follows and

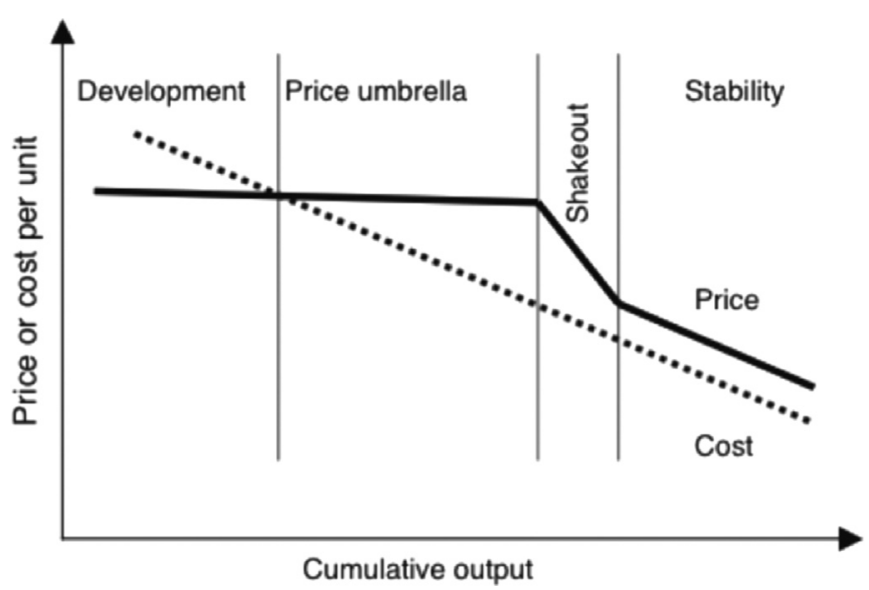

Fig. 1. Development of costs and prices of emerging technologies (Boston Consulting Group, 1968). 
leads to lower prices; at some point the profit margins will become so small that competitors will leave the market (shakeout). From this point the decline of costs and prices is equal, so in principle the experience curve based on prices can only be used from this point onwards. Although this is a general framework without any clear indications regarding the amount of competitors or cumulative output, it can be used to understand to development of a technology regarding the difference between prices and costs.

\subsection{Levelized cost of electricity}

LCoE of offshore wind farms is calculated using Eq. (1). The LCoE is equal to the discounted lifetime costs divided by the discount lifetime energy production.

$L C O E=\frac{C A P E X+\sum_{t=1}^{L} \frac{\text { OPEX }}{(1+i)^{t}}}{\sum_{t=1}^{L} \frac{A E P}{(1+i)^{t}}}$

In this formula $i$ is the discount factor, similar to other research this is assumed to be similar to the Weighted Average Cost of Capital (WACC) (Fichter and Prognos, 2013; Levitt et al., 2011), $t$ is the year of operation, which goes up to a lifetime $L=20$ year, AEP is the Annual Energy Production, which is based on the capacity factor (including transport losses to shore) and finally OPEX stands for Operational Expenditures. The WACC is an expression of the financing costs of a project expressed as a rate of return. It is the weighted average of the required returns on the debt and equity:

WACC $(\%)=$ share of equity $\times$ cost of equity $(\%)+$ share of debt

$$
\times \text { cost of debt (\%) }
$$

\section{Methods}

In order to analyse the price developments, an offshore wind energy cost model is combined with data of operational OWFs. First the cost model is explained and secondly the data collection of the wind farms is presented, followed by a description of analysis of CAPEX and calculation of LCoE.

The model is a result of the FLOW project by TKI-WoZ (Top consortium for Knowledge and Innovation Offshore Wind) (TKIWoZ, 2015). FLOW stands for Far and Large Offshore Wind, it is a Dutch R\&D program focussing on innovations that can reduce the costs of offshore wind. Its partners are: 2-B Energy, Ballast Nedam, ECN, Eneco, IHC Merwede, RWE, TenneT, TU Delft, Van Oord and XEMC Darwind. The model is a cash flow model that uses an engineering approach to calculate the costs of a specific wind farm. The original goal of the model is to indicate how costs change due to location site but also how commodity prices, the political framework or any other financial and technical characteristics effect cost changes. The detailed content and data of the model is confidential but a brief version of the model can be found online (FLOW, 2015). The cost data of the model was gathered from the FLOW partners (FLOW, 2014). Part of the model has also been used by IEA wind Task 26 (IEA wind, 2015), which studies the cost of wind energy. In order to assess the reliability of the model, 10 existing OWFs have been included in the model to calculate the CAPEX. The calculated CAPEX was compared with the published CAPEX of each OWF. On average, calculated and actual CAPEX values differed by $-0.7 \%$ with a standard deviation of $9.8 \%$. As the CAPEX depends on many different financial agreements the model thus is deemed accurate enough to use for this research (Prinsen, 2014).

The included characteristics of each OWF are presented in
Table 1

Included characteristics of selected wind farms for the database.

\begin{tabular}{ll}
\hline Characteristics & Unit/classification \\
\hline CAPEX & M€/MW' \\
Date & Month and year when the project was \\
& fully commissioned \\
Capacity OWF & MW \\
Turbine capacity & MW \\
Turbine manufacturer & Siemens, Vestas, Senvion, etc. \\
Country & BE,DE,DK,IR,NL,SW,UK \\
Depth (average of OWF) & $\mathrm{m}$ \\
Support structure & Monopile, tripod, jacket, gravity-based, \\
& tripile \\
Distance to shore & $\mathrm{km}$ \\
Export cable length and type & $\mathrm{km}$ and MVAC, HVAC, HVDC \\
10 year average wind speed @ hub & $\mathrm{m} / \mathrm{s}$ \\
$\quad$ height & $\mathrm{GWh} / \mathrm{y}$ or \% \\
Annual energy production or capa- & \\
$\quad$ city factor & $\mathrm{W} / \mathrm{m}^{2}$ \\
Power density of turbine & Yes or no \\
Offshore transformer station &
\end{tabular}

a Other currencies are converted to Euros, based on the exchange rate of the moment on which the OWP became operational.

Table 1, and collected in a database. The characteristics of OWFs have primarily been extracted from the online database "4coffshore", also used in other scientific literature (Prässler and Schaechtele, 2012). This database contains specific information about each OWF. If data was missing, other sources were used to complete the database. The performance of OWFs is based on the capacity factor. For OWFs in Denmark and the United Kingdom recent figures were found at Energynumbers (2014) and Variablepitch (2015). Other missing data was collected from different websites mainly, offshore wind energy websites and project developers' websites.

\subsection{CAPEX developments}

The goal is to exclude the influence of several external factors in order to see how much of the CAPEX increase is caused by these factors. This was done in the following three steps:

1. Applying a uniform definition of CAPEX,

2. Excluding the effect of OWFs moving further from shore,

3. Excluding the effect of commodity price changes.

It seems logical that the definition of CAPEX should be equal for each OWF in order to analyse the developments. Surprisingly this is not common practice, it depends on the responsibilities of the Transmission System Operator (TSO) (Levitt et al., 2011). Therefore, the first step is to calculate the CAPEX for each OWF based on one uniform definition. Our CAPEX definition includes the grid connection up to the onshore transformer.

In order to exclude the effect of increasing distance to shore and depth, the CAPEX of each OWF were recalculated as if it would have been built on a baseline location. Based on the average characteristics of the OWF, the baseline location was defined as a depth of $15 \mathrm{~m}$ and a distance to shore of $15 \mathrm{~km}$, with an export cable length of $15 \mathrm{~km}$ (HVAC). OWF's close to shore ( $<10 \mathrm{~km}$ ) typically do not have an offshore high voltage transformer (OHVS); however for $15 \mathrm{~km}$ distance to shore it is beneficial to install an OHVS. Therefore, the CAPEX for the baseline location will be calculated assuming that each OWF will have an OHVS installed.

A similar approach was applied to exclude the influence of fluctuating commodity price levels. Steel, copper and oil have significant influences on the prices of specific components (Table 2). To exclude the influence of commodity price fluctuations, 
Table 2

The share of commodities related to the price of important offshore wind energy components.

\begin{tabular}{lllll}
\hline & Turbine (\%) & $\begin{array}{l}\text { Monopile foundation } \\
(\%)\end{array}$ & $\begin{array}{l}\text { Jackets foundation } \\
(\%)\end{array}$ & Cable (\%) \\
\hline Steel & 30 & 40 & 35 & 5 \\
Copper & 10 & 0 & 0 & 45 \\
Oil & 15 & 20 & 15 & 10 \\
Others & 45 & 40 & 50 & 40 \\
\hline
\end{tabular}

the CAPEX of each OWF is recalculated based on the average price of 2013.

When comparing the CAPEX of OWFs from different year, the costs are presented in real 2013 Euros. This is done using European inflation rates (ECB, 2015). However, as increases in commodity prices are also partially reflected in inflation rates, there is an overlap between commodity prices and inflation, leading to the issue of double counting (Boughton and Branson, 1988). To prevent this, nominal values of the CAPEX will be used during this step of the analysis. So only the original CAPEX data will include inflation. The CAPEX data that will be corrected for commodity prices will be based on the original prices excluding inflation.

\subsection{LCoE developments}

To calculate the LCoE of each project, it has been attempted to find specific data for each project, however, only CAPEX and capacity factors were found specifically for each project. Therefore, assumptions have been made based on literature and expert opinions to estimate figures related to the WACC and OPEX. For LCoE analyses, the original CAPEX figures were used rather than the CAPEX corrected for distance to shore etc., as we wanted to gain insights in real LCoE trends. Also, using corrected CAPEX in LCoE calculations would have required additional assumptions for variables such as wind speed and load factor, which would have introduced additional uncertainty.

\section{Results and discussion}

\subsection{Development of offshore wind energy}

Overall, the database contains 46 OWFs with a total capacity of 8.514 GW. The oldest OWF is Middelgrunden and the most recent is Global Tech 1. Before analysing the cost development, it is important to point out the technological developments offshore wind has gone through since 2000. Table 3 presents average characteristics of wind farms over three 5-year periods; additionally the most extreme values are also presented with the

Table 3

Development of offshore wind farms from 2000 to 2015 .

\begin{tabular}{|c|c|c|c|c|}
\hline \multirow{2}{*}{$\begin{array}{l}\text { Average } \\
\text { characteristics }\end{array}$} & \multicolumn{3}{|l|}{ Period } & \multirow{2}{*}{$\begin{array}{l}\text { Maximum values in } \\
\text { database }\end{array}$} \\
\hline & $\begin{array}{l}2000- \\
2005\end{array}$ & $\begin{array}{l}2005- \\
2010\end{array}$ & $\begin{array}{l}2010- \\
2015\end{array}$ & \\
\hline CAPEX $\left(\mathrm{M} €_{2013} / \mathrm{MW}\right)$ & 2.1 & 2.8 & 4.1 & 7.25 (Bard 1) \\
\hline $\begin{array}{l}\text { Turbine Capacity } \\
\text { (MW) }\end{array}$ & 2.3 & 3.2 & 3.8 & $\begin{array}{l}6.15 \text { (Senvion } \\
\text { turbine) }\end{array}$ \\
\hline Capacity OWF (MW) & 76.3 & 102.9 & 253.6 & 630 (London Array) \\
\hline $\begin{array}{l}\text { Distance to shore } \\
(\mathrm{km})\end{array}$ & 8.8 & 13.7 & 30.0 & 115 (Global tech 1 ) \\
\hline Water depth (m) & 9.1 & 12.4 & 20.8 & $\begin{array}{l}40 \text { (Bard } 1 \text { and Glo- } \\
\text { bal tech } 1 \text { ) }\end{array}$ \\
\hline
\end{tabular}

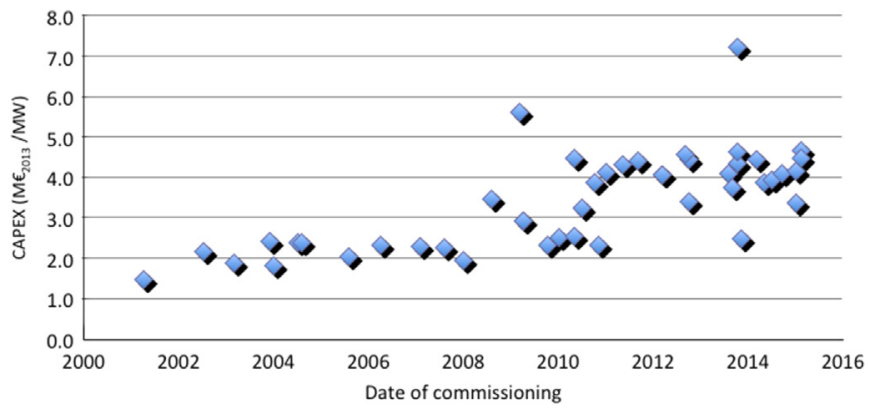

Fig. 2. CAPEX developments of offshore wind farms from 2000 to January 2015.

corresponding turbine or OWF. Overall, CAPEX and turbine capacity and depth have approximately doubled while wind farm capacity and distance to shore have more than tripled. The column with the maximum values indicate the large variety between offshore wind farms, additionally these most extreme values are expected to become the new standard for future offshore wind farms (except CAPEX).

The CAPEX of the 46 OWFs included in this research is presented in Fig. 2. Although the CAPEX increased several learning effects can be observed. For example, JRC (2014) concluded that monopile installation time decreased from 4.0 to 2.0 days per MW. Due to a lack of insights in costs of installation vessels, this cannot be expressed in a CAPEX reduction. However, it is likely that installation costs decreased as vessel rates are expressed per day. Most likely this increased efficiency is a result of learning by doing.

Another noticeable learning effect is the increase of rotor diameter (upscaling and redesigning). The ratio between turbine capacity and swept rotor area is the power density $\left(\mathrm{W} / \mathrm{m}^{2}\right)$. In theory, a bigger rotor diameter with identical rated capacity leads to a lower power density. This means less energy (lower wind speeds) are required to reach the rated capacity of a turbine. Ultimately, this results in a higher capacity factor (CF) (Zaaijer, 2014). A trend that has taken place several times in the past 15 years is that turbine suppliers increase the rotor diameter of an existing turbine after it has been operational for several years (De Vries, 2011). Table 4 presents the effect of a bigger rotor diameter on the capacity factor for the turbines with the biggest market share in the offshore wind energy sector. First the Siemens 3.6 MW had a 107$\mathrm{m}$ rotor diameter, which later increased to $120 \mathrm{~m}$. Based on our database, the OWFs with the 3.6-107 turbine have a CF of $36 \%$ while the OWFs with the 3.6-120 have a $43 \% \mathrm{CF}$, an increase of $19.4 \%$, which lowers LCoE values typically by $15-20 \%$. In 2013 , Siemens further developed this model into a $4.0 \mathrm{MW}$ turbine with a $130 \mathrm{~m}$ rotor diameter resulting in a power density of $300 \mathrm{~W} / \mathrm{m}^{2}$ (Siemens, 2013). This will most likely further increase the capacity factor of this new model.

Table 4

Development of 3.6 MW Siemens turbine model.

\begin{tabular}{lllll}
\hline $\begin{array}{l}\text { Turbine } \\
\text { model }\end{array}$ & $\begin{array}{l}\text { Installed ca- } \\
\text { pacity (MW) }\end{array}$ & $\begin{array}{l}\text { Market } \\
\text { share }^{\mathrm{a}}(\%)\end{array}$ & $\begin{array}{l}\text { Average ca- } \\
\text { pacity factor } \\
(\%)\end{array}$ & Power density $\left(\mathrm{W} / \mathrm{m}^{2}\right)$ \\
\hline $\begin{array}{c}\text { Siemens } \\
\begin{array}{c}3.6-107 \\
\text { Siemens } \\
3.6-120\end{array}\end{array}$ & 1462 & 23 & 36 & 401 \\
\hline
\end{tabular}

${ }^{\text {a }}$ Market share is expressed as percentage of total installed capacity in database. 
Table 5

Specific costs related to distance to shore.

\begin{tabular}{|c|c|c|c|}
\hline Stage & Component & Cost & Based on \\
\hline \multirow[t]{3}{*}{ Supply } & Export cable $33 \mathrm{kV}$ & $400 € / \mathrm{m}$ & Export cable length \\
\hline & Export cable $66 \mathrm{kV}$ & $475 € / \mathrm{m}$ & Export cable length \\
\hline & Offshore transformer & $0.21 \mathrm{M} € / \mathrm{MW}$ & $\begin{array}{l}\text { Presence of offshore } \\
\text { transformer station }\end{array}$ \\
\hline \multirow[t]{2}{*}{ Installation } & Export cable & $400 € / \mathrm{m}$ & Export cable length \\
\hline & Monopiles + turbines & $4000 € / \mathrm{MW} / \mathrm{km}$ & Distance to shore \\
\hline
\end{tabular}

\subsection{CAPEX analyses}

As previously stated, the definition of CAPEX differs per country. In the UK, NL and Belgium, CAPEX includes everything up to the onshore transformer (Dong Energy, 2014). In Germany, it includes everything up to the OHVS but not a HVDC station if a HVDC connection is used. In Denmark CAPEX only covers everything up to the array cables, as the TSO is responsible for all components up to the OHVS. Transmission system assets can cover up to $25 \%$ of the total CAPEX and therefore this boundary of the CAPEX has a big impact when analysing the CAPEX on a European level. To our knowledge, such a correction of the CAPEX definition has not taken place. Although the difference has been recognized (Levitt et al., 2011) it has not been attempted to convert the CAPEX of operational OWFs to the UK definition, for example. The definition of CAPEX applied in this paper includes everything up to the onshore transformer. As a result, the CAPEX of the OWFs in Germany and Denmark on average increased with $20 \%$ and $18 \%$, respectively. Although this increase is significant, the average CAPEX development as presented in Fig. 2 did not change much.

The next step was to exclude the effect of location. This was done by recalculating the costs for the grid connection and support structures for the baseline location. Cost data related to distance to shore is presented in Table 5.

To correct the CAPEX for depth, it was assumed that only support structure costs are affected. The data from the FLOW model related to support structures and depth is presented in Fig. 3. Each OWF was classified by support structure type (monopile or jacket) and turbine class (3, 5 or $7 \mathrm{MW}$ ) in order to be able to calculate the change in the CAPEX.

The impact of this correction on CAPEX is not significant. It mainly increased the CAPEX of projects before 2008, while CAPEX of projects after 2008 decreased. But overall, the CAPEX still increases from about 2.0 to 4.0 M€/MW instead of 1.5 to $4.5 \mathrm{M} € / \mathrm{MW}$ for the original CAPEX.

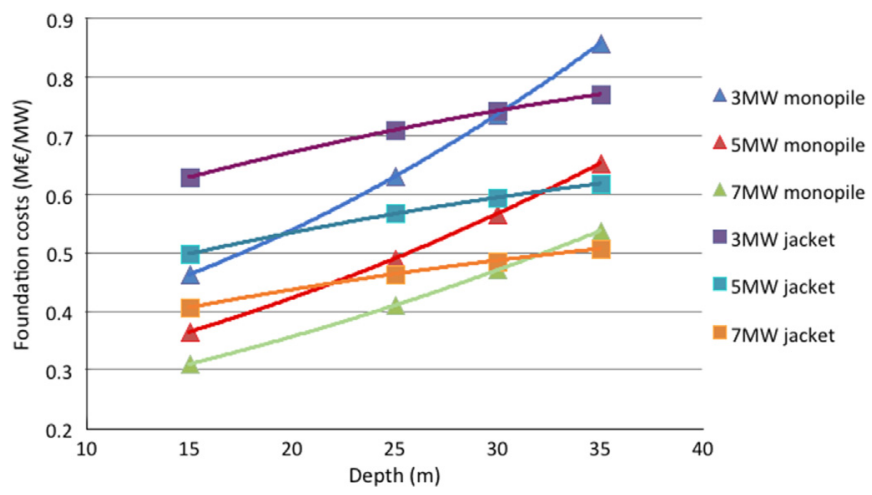

Fig. 3. Support structure costs $(\mathrm{M} € / M W)$ related to depth (data extracted from FLOW model).

\subsubsection{Commodities price levels}

For the production of an offshore wind farm, large quantities of steel, copper and oil are required (Dong Energy, 2013). As commodity prices have greatly fluctuated since 2000 , this has had a big impact on the prices of offshore wind energy (UKERC, 2010). Additionally, commodity prices increased by a factor 2 or 3 between 2000 and 2011 followed by a decrease up to 2014 as the global economy slowed down (IMF, 2012; The Economist, 2014).

The biggest challenge was to link commodity prices to each OWF. Relevant questions are: what was the steel price paid for by the different suppliers? And when were the materials bought and how were the risks spread between the manufacturer and the project developer? Van der Zwaan et al. (2012) studied the effect of commodity prices on the CAPEX of offshore wind but did not include a time delay. After analysing several project timelines (Accenture, 2013; RenewableUK, 2014a; Belwind, 2014) it appears that on average, an OWF is fully commissioned $2-2.5$ years after a Final Investment Decision (FID) is reached. Therefore, it is assumed the prices of components are agreed upon at the FID based on the commodity prices of that moment. In our analysis, we decided to link the average commodity prices of 2-2.5 years before the commissioning took place to the OWFs.

The next step was to determine the costs of the specific components per OWF, as only the CAPEX is known. This was done using the FLOW model, each OWF already had been adjusted to the baseline locations, meaning that cable and support structures shares are similar for each OWF. Based on the support structure type and turbine capacity of each OWF, the share of the CAPEX of the turbine, support structure, cable and installation were determined. The final step was to recalculate the CAPEX of each OWF based on standard commodity prices, 2013 average prices were chosen as this standard. With these steps we excluded the influence of commodity prices from the CAPEX development of offshore wind energy.

Fig. 4 presents the 'original' CAPEX development and the 'corrected' CAPEX after applying a uniform definition and excluding the influence from location and commodity prices. The difference between the trend lines presents that uniform definition, location site, and commodity prices are only partially responsible for the CAPEX increase. The linear trend line of corrected CAPEX still shows an increase from 2.8 to $4.1 \mathrm{M} € / \mathrm{MW}$.

Additionally, a difference between the periods before and after 2008 is observed. In the first period, the original CAPEX increase is much lower compared to the later period. The 'corrected' CAPEX shows a slowly decreasing trend of the CAPEX during 2000-2008 followed by an increase during 2008-2015. These findings suggest that location type and commodity prices have been mainly responsible for the CAPEX increase from 2000 to 2008, while after 2008 , other factors drove the increase of the CAPEX.

\subsubsection{Effect of limited competition in the market}

The fact that location and commodity prices have not caused the full CAPEX increase suggests that there are other influences. For example, several sources have expressed there are several bottlenecks in the supply chain of offshore wind. These bottlenecks are related to turbine supply, availability of installation vessels and cable installation (JRC, 2014; UKERC, 2010). Despite the rapid growth of offshore wind energy, the number of suppliers is still relatively small. In several segments of the sector there does not seem to be much competition between firms. These monopolies or oligopolies can lead to less innovation and higher profit margins, as there is no incentive to reduce market prices (Boston Consulting Group, 1968; Windpower monthly, 2012).

The best example of a limited amount of competitors is the turbine supply. Siemens supplied turbines for 23 of the 45 OWFs in the database with a capacity of $5.2 \mathrm{GW}$ ( $62 \%$ of total capacity). In 2014, Siemens had a market share of 86.2\% (EWEA, 2015). Other 


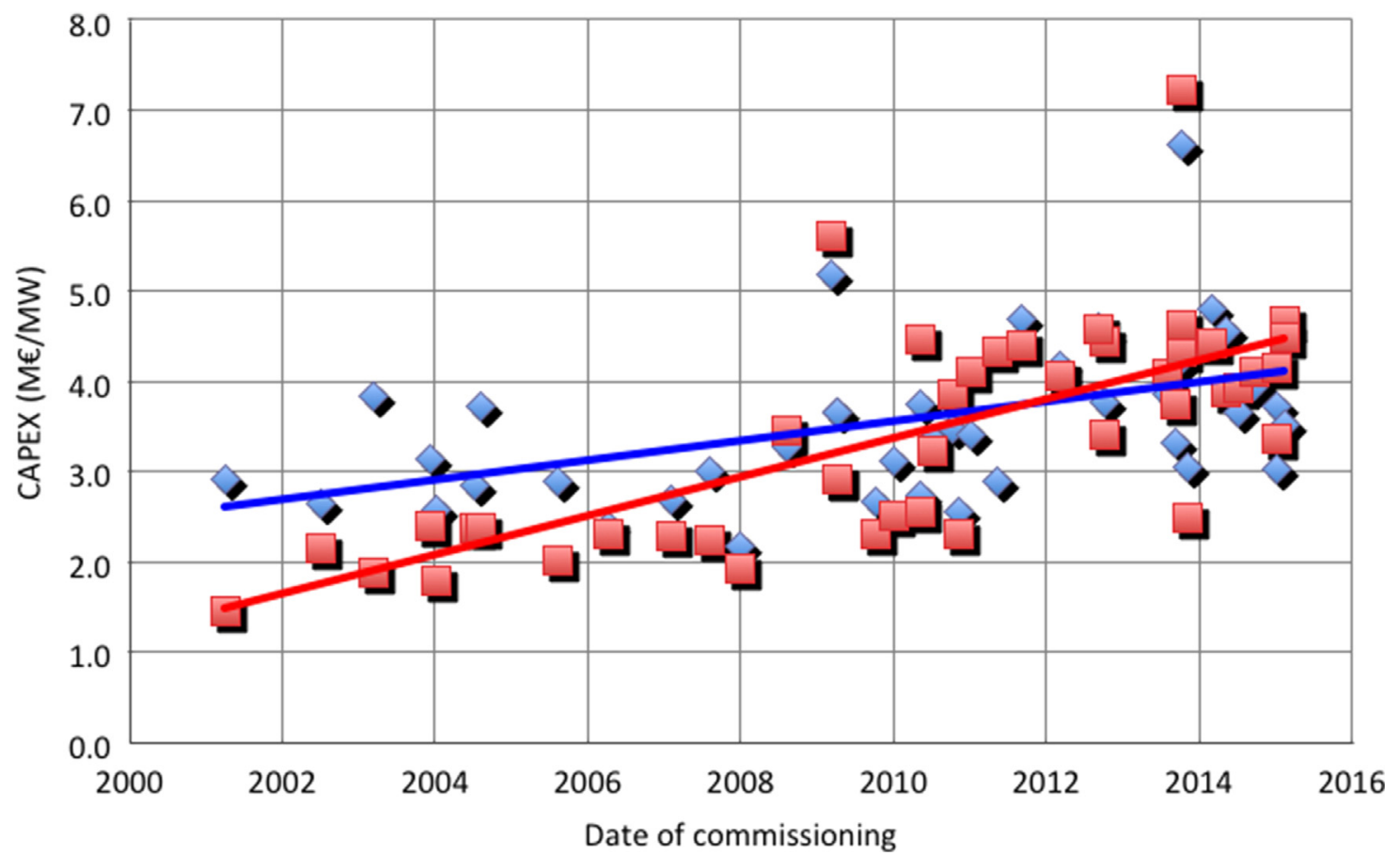

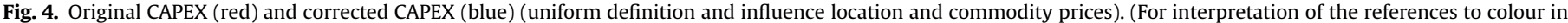
this figure legend, the reader is referred to the web version of this article.)

submarkets with limited competition are construction services and grid connections. With the recent merger of Van Oord and Ballast Nedam Offshore, Van Oord became market leader within the installation of offshore wind farms. Regarding grid connections, there are three countries in which the transmission system operator is responsible for the grid connection. The biggest issue of analysing specific component prices is that they are generally not published. Bloomberg New Energy Finance (World Energy Council, 2013) has presented a doubling for onshore wind turbine prices from 2000 to 2008 followed by a decrease again. However, such data is not available for offshore turbine prices. Table 6 shows an inventory of turbine prices found in literature and recent turbine contracts. Although the amount of data points is limited and relate to different turbine models, these figures suggest a significant increase in turbine prices has taken place from 2009 to 2014. Therefore it seems very likely turbine prices have been responsible for a significant CAPEX increase, which cannot be explained by location and commodity prices.

\subsection{Analyses of LCoE development}

In this second part of the research the LCoE development is analysed. First, it is presented how the required input for

\section{Table 6}

Overview of recent turbine prices.

\begin{tabular}{|c|c|c|c|}
\hline Source/project & Year & $\begin{array}{l}\text { Turbine prices } \\
(\mathrm{M} € / \mathrm{MW})\end{array}$ & Remarks \\
\hline EWEA & 2009 & 0.92 & Average figure \\
\hline IRENA & 2012 & 1.5 & Average figure \\
\hline Butendiek & $2011^{\mathrm{a}}$ & 2.4 & $\begin{array}{l}\text { Including } 10 \text { year O\&M contract } \\
\text { (Siemens } 3.6-120 \text { ) }\end{array}$ \\
\hline Gwynt Y mor & $2012^{\mathrm{a}}$ & 2.0 & (Siemens 3.6-107) \\
\hline Gemini & $2014^{\mathrm{a}}$ & 2.5 & $\begin{array}{l}\text { Including } 15 \text { year O\&M contract } \\
\text { (Siemens } 4.0-130 \text { ) }\end{array}$ \\
\hline Dudgeon & $2014^{\mathrm{a}}$ & 1.8 & (Siemens 6.0-154) \\
\hline
\end{tabular}

\footnotetext{
${ }^{\text {a }}$ Refers to date of turbine contract being signed.
}

calculating the LCoE has been gathered. Secondly, the development of the LCoE is analysed and country specific development are presented.

\subsubsection{Capacity factor}

The energy production of an OWF is generally expressed in the Capacity Factor (CF) or the Annual Energy Production (AEP). Ultimately the AEP or CF should be known for every year the OWF has been operational; however typically these figures are only available for 1 or 2 years. Therefore, the assumption has been made that the capacity factor of one specific year is equal to the lifetime average, while the capacity factor can vary largely based on variation in wind speeds and availability of the wind farm (Barthelmie et al., 2010). The newest OWFs included in the database have not been operational for more than a year, in order to give an indication of the LCoE of these most recent windfarms a capacity factor of $40 \%$ is assumed.

Overall the capacity factor has increased from 25\% in 2001 (Middelgrunden), beyond 40\% in 2014, several OWFs (Alpha Ventus, Horns Rev 2, Anholt 1) even reported capacity factors of $50 \%$. This increase of the capacity factor indicates that technology developed and efficiency improved, this should have a positive effect on the development of the LCoE.

\subsubsection{Financing costs}

Recent large-scale projects can have a CAPEX over 2 billion euro and require large quantities of debt and equity. Generally

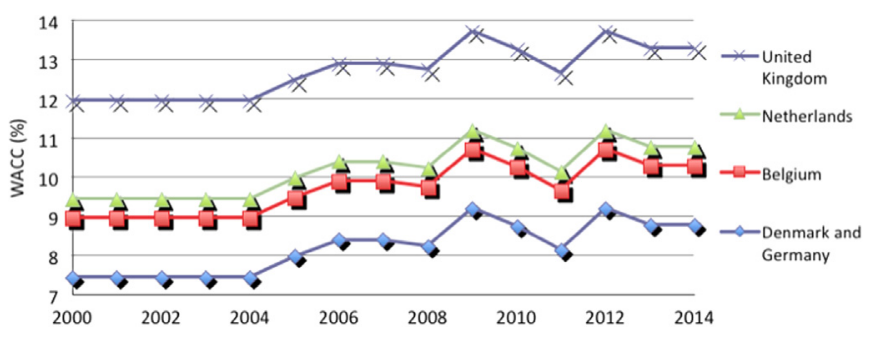

Fig. 5. Calculated development of WACC per country from 2000 to 2014 . 
speaking, the ratio of debt and equity is published for specific projects but not the costs (annual rate of return). The ratio of debt and equity (also known as gearing) is typically 70:30. The costs of debt and equity are a result of several factors: general economic welfare, technology related risks and in the case of offshore wind also policy risks (3E, 2012). In order to calculate the WACC for each OWF, the WACC is calculated specifically for each country per year (3E, 2013; Green Giraffe; 2013), see Fig. 5. Overall, the WACC has increased by 150 basis points (bps) for each country as a result of the financial crisis (Green Giraffe, 2013; EWEA, 2013). However, due to unstable or unpredictable policy frameworks the WACC can be as large as $450 \mathrm{bps}$, which will have a significant effect on the LCoE. The WACC in the UK is relatively high due to several market mechanisms in the policy framework, which make the financial support per MWh flexible. Additionally, there is an increased risk for investors from Euro countries due to currency fluctuations (3E, 2013). This big difference between the UK and Denmark corresponds to the WACC presented in other sources (CEPA, 2011; Granheim et al., 2012).

To quantify the importance of WACC, as an example, the LCoE of OWFs in the UK would be reduced by approximately $22 \%$ if the WACC of Denmark would be applied. This indicates the big impact of the political framework and long term stability relating the cost of finance and therefore the LCoE. Overall the impact of the $150 \mathrm{bps}$ increase of the WACC results in an $8 \%$ increase in the LCoE. This indicates financing costs have contributed to increasing the LCoE.

\subsubsection{Operational expenditures}

Similar to financing costs, annual operating expenditures (OPEX) are not published for specific projects. Limited data is available, partially because most turbines are still under warranty for a 15-year period (Navigant, 2014). Before quantifying the annual costs, it is important to state the difference between O\&M and OPEX: OPEX includes O\&M but also any other annual operating expenses. It is estimated that O\&M is about $50 \%$ of the total OPEX for offshore wind (IRENA, 2012; SETIS, 2011).

As data was not available for specific OWFs, it was attempted to come up with OPEX figures based on characteristics of the wind farms such as distance to shore, date and turbine capacity. As literature could not provide any insights, several experts were contacted. They indicated there are no clear trends in O\&M or OPEX for offshore wind based on any general characteristics (Prinsen, 2014; Lacal Arántegui, 2014). Ultimately, an average figure of $160 \mathrm{k}$ $€ / \mathrm{MW} /$ year was used for each OWF which is also used by other sources (IRENA, 2012; SETIS, 2011; BVG, 2012). Therefore, it is assumed in this research that the OPEX did not influence the development of the $\mathrm{LCOE}$.

\subsubsection{Development of $L C O E$}

With Eq. (1) and the presented input for each OWF, the LCoE for each project has been calculated and is presented in Fig. 6. The red line indicates the point in time from which the capacity factor is assumed to be $40 \%$ due to the fact that these OWFs have not been operating for at least one year.

As shown in Fig. 6 the LCoE of offshore wind energy has increased from around 100 towards $200 € / M W h$, including a rapid increase and large variation between 2008 and 2012. After 2013, the LCoE appears to start decreasing, but given the large spread, it remains to be seen if this is truly a trend and whether it will continue in the future. Overall Fig. 6 presents a similar development as the LCoE development published by IRENA (2015). The increase of the LCOE is not surprising, as the CAPEX tripled since 2000 and the LCoE is on average determined by the CAPEX for $70 \%$ (INNWIND, 2014). Fig. 7 presents the LCoE of OWFs distinguished per country. This provides very different insights compared to the average LCoE development presented in Fig. 6.

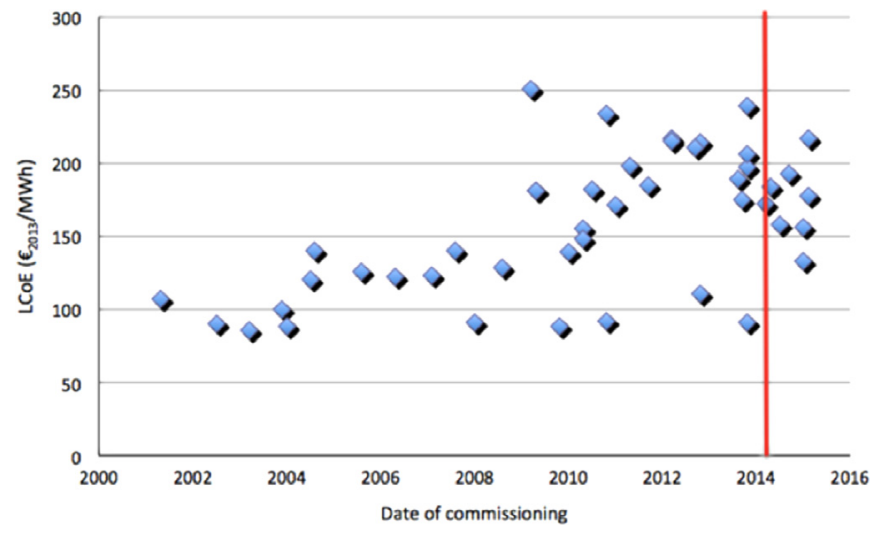

Fig. 6. Calculated LCoE of the operational offshore wind farms. For OWFs right of the straight line at 2014 , a CF of $40 \%$ has been assumed.

The trend lines present the development of the LCoE for each country having offshore wind energy. Most striking is the difference between the developments of different countries. In the UK, the LCoE increased from $120 € / \mathrm{MWh}$ to over $200 € / \mathrm{MWh}$, while in Denmark, the LCoE has remained rather constant just below $100 € / \mathrm{MWh}$.

The linear trend lines of Denmark and the United Kingdom match rather well with the individual data points. For the Netherlands and Sweden, with only two OWFs each, it is not possible to determine a trend. Belgian LCoE values appear to decrease, whereas the average German LCoE values are constant, but the limited amount of data points and large spread does not allow for clear conclusions. To explain the difference in the LCoE development of specific countries, the characteristics of OWFs in Denmark and the United Kingdom were analysed in more detail.

Table 7 presents several important factors related to the LCoE development in the United Kingdom and Denmark. In both countries, the CAPEX has doubled and in both countries the WACC increase is assumed to be similar, although both the CAPEX and the WACC are higher in the UK. More interesting is the development of the capacity factor: in the UK, it increased from 33\% to $39 \%$, while in Denmark it doubled from 25\% to 50\%; this is remarkable when considering the average wind speed is $0.5 \mathrm{~m} / \mathrm{s}$ higher on UK locations compared to Danish locations. Overall, the strong increase of the capacity factors in Denmark has been able to compensate the doubling of the CAPEX. Therefore, the Danish LCoE is constant while it has almost doubled in the UK.

As previously stated, increasing the rotor diameter has had a positive effect on the capacity factor. From Fig. 8 it can be seen that most recent OWFs have a lower power density compared to the older OWFs. In the UK, the use of the Siemens 3.6-107 model is clearly visible at $400 \mathrm{~W} / \mathrm{m}^{2}$. This turbine has been used from 2003 up to 2013 and it is still used in OWFs currently under construction (e.g. Gwynt Y Mor (576 MW)). Also, the capacity factors of OWF in both countries are presented: it shows how the performance in Denmark increased much faster, while in the UK there is a lot more variation around the linear trend.

All the operational OWFs in the UK have been part of the tender rounds 1 and 2, which took place in 2001 and 2003. The locations and characteristics of these wind farms have been planned and partially laid out in 2001 and 2003 respectively (RenewableUK, 2014b). This means that characteristics of many of the technological components have already been determined based on the available technologies in those years (example of the Siemens 3.6107). A good example is OWF Teesside, part of round 1: first plans were made in 2001, but it only became fully operational in April 2014 using 2.3 MW turbines - clearly outdated, as 7 and 8 MW turbines are currently being selected for new projects. In Denmark, the average time for an OWF to become fully operational is about 


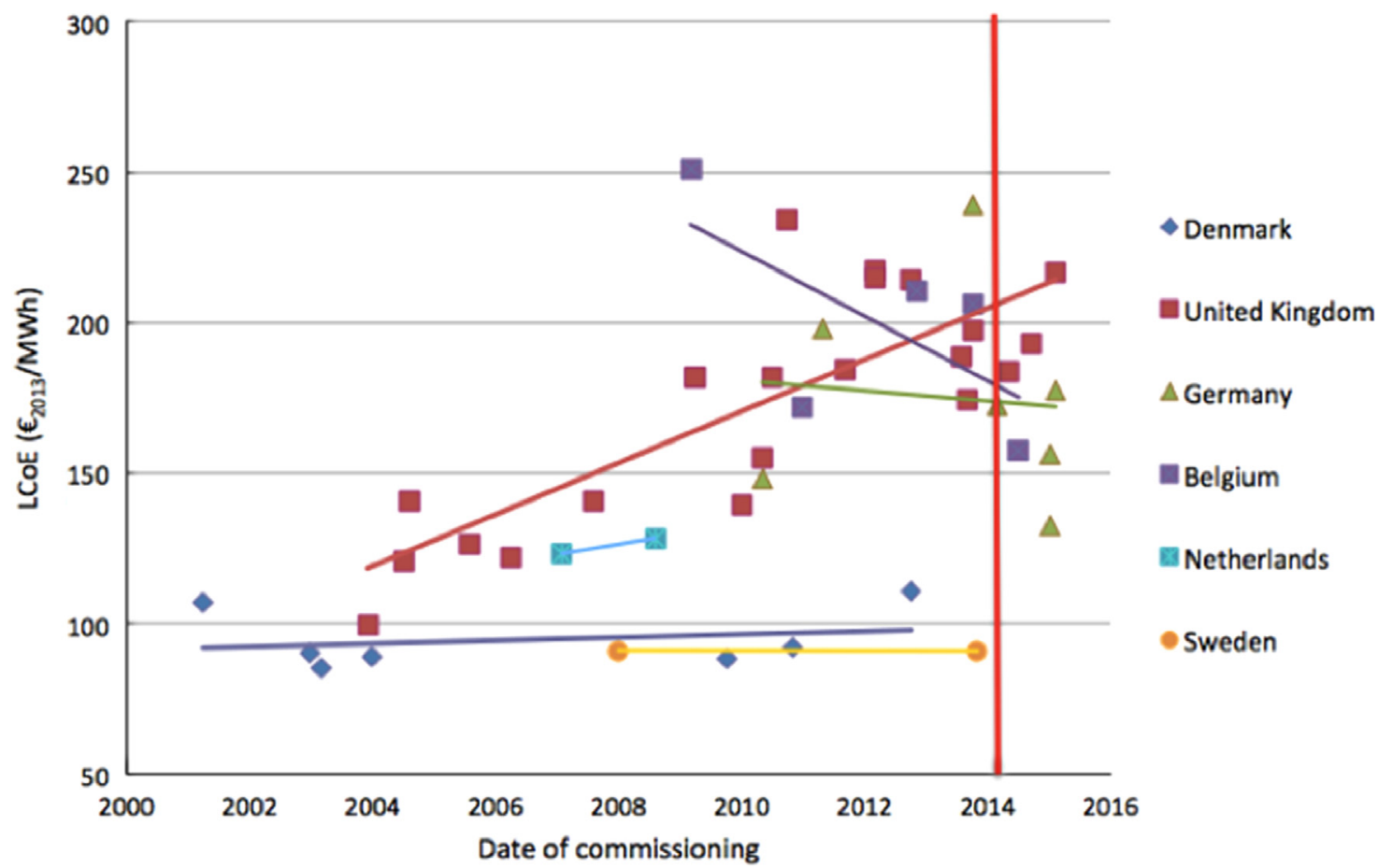

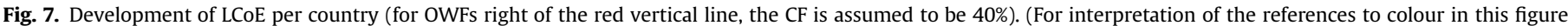
legend, the reader is referred to the web version of this article.)

Table 7

Developments of offshore wind farm characteristics in United Kingdom and Denmark.

\begin{tabular}{lllll}
\hline & \multicolumn{2}{l}{ United Kingdom } & \multicolumn{2}{l}{ Denmark } \\
\hline Year & 2004 & 2015 & 2001 & 2013 \\
LCoE $\left(€_{2013} / \mathrm{MWh}\right)$ & 120 & 220 & 95 & 100 \\
CAPEX $\left(\mathrm{M} €_{2013} / \mathrm{MW}\right)$ & 2.0 & 4.4 & 1.5 & 3.0 \\
WACC $(\%)$ & 12.0 & 13.4 & 7.4 & 8.9 \\
Wind speed at hub height $(\mathrm{m} / \mathrm{s})$ & 9.6 & & 9.1 & \\
Capacity factor $(\%)$ & 33 & 39 & 25 & 50 \\
Power density $\left(\mathrm{W} / \mathrm{m}^{2}\right)$ & 440 & 360 & 440 & 320 \\
\hline
\end{tabular}

4 years. This allows Danish OWF's to use more modern technologies compared to UK wind farms, and therefore are able to keep improving the energy performance of offshore wind farms.

In February 2015 two reports were published confirming the big difference between the UK and Denmark as found in this paper: the estimated LCoE of the yet to be built wind farm Horns Rev 3 is $103.1 € / M W h$ (Windpowermonthly, 2015), while in the UK, projects completed in 2012-2014 had an LCoE of $182 € / \mathrm{MWh}$ (131 £/MWh) (ORE Catapult, 2015).

In 2011, a revision was made to the Development Consent Order, a so-called 'Rochdale Envelope' was applied. This revision makes it possible for project developers to change certain characteristics of a project. At the same time, the Environmental Impact Assessment (EIA) has to be carried out taking into account the need for such evolution, within those parameters, and reflects the likely significant effects of such a flexible project in the environmental statement (IPC, 2011). This approach was not available to any of the operational OWFs used in this research, but it will provide more flexibility for future OWFs.

\section{Conclusions and policy implications}

The aim of this research was to provide insights in the historical cost developments of offshore wind energy in Europe. It is one of the first to analyse the cost developments based on operational offshore wind farms. The biggest challenge was acquiring detailed cost information of specific projects. Almost all contracts are confidential, making it difficult to analyse cost developments of specific components. Not only are cost data rarely available, but also complex due to different contract schemes and other agreements. This lack of transparency seems conflicting with the fact that offshore wind energy still depends on financial support from governments, while the sector claims it is really making an effort to reduce the $\mathrm{LCoE}$.

The results indicate that applying a uniform definition of CAPEX and excluding the effect of changing location sites and commodity prices does not explain the increase in CAPEX completely. Roughly speaking only half of the increase is explained by these factors. It appears that limited market competition also resulted in price increases, but it was not possible to quantify this.

Although an experience curve has not been constructed for offshore wind energy since 2000 , there are clear signs of technological learning in the data presented in this paper. The rapid growth of installed capacity and R\&D efforts has led to learningby-doing and learning-by-searching and also the design has been redefined and up scaled. Although there are clear signs of technological learning it did not directly lead to lower prices.

Looking at the overall development of the LCoE, it can be concluded that the tripling of the CAPEX resulted in a doubling of the LCoE. The increase of the capacity factor has been the most important factor for lowering the LCoE. This research shows that the LCoE differs greatly among European countries, in the UK LCoE increased from 120 to $220 € / M W h$ while in Denmark it remained constant just below $100 € / \mathrm{MWh}$. As $55 \%$ of the total capacity is located in the UK, the LCoE development is largely influenced by the prices in the UK. Other countries with multiple large scale OWFs (Germany and Belgium) show at least constant or a decreasing LCoE development.

It seems that the most important reason for this difference is a rather low and constant capacity factor in the UK. Its value is around 35\%, while in Denmark each new OWF reported a higher 

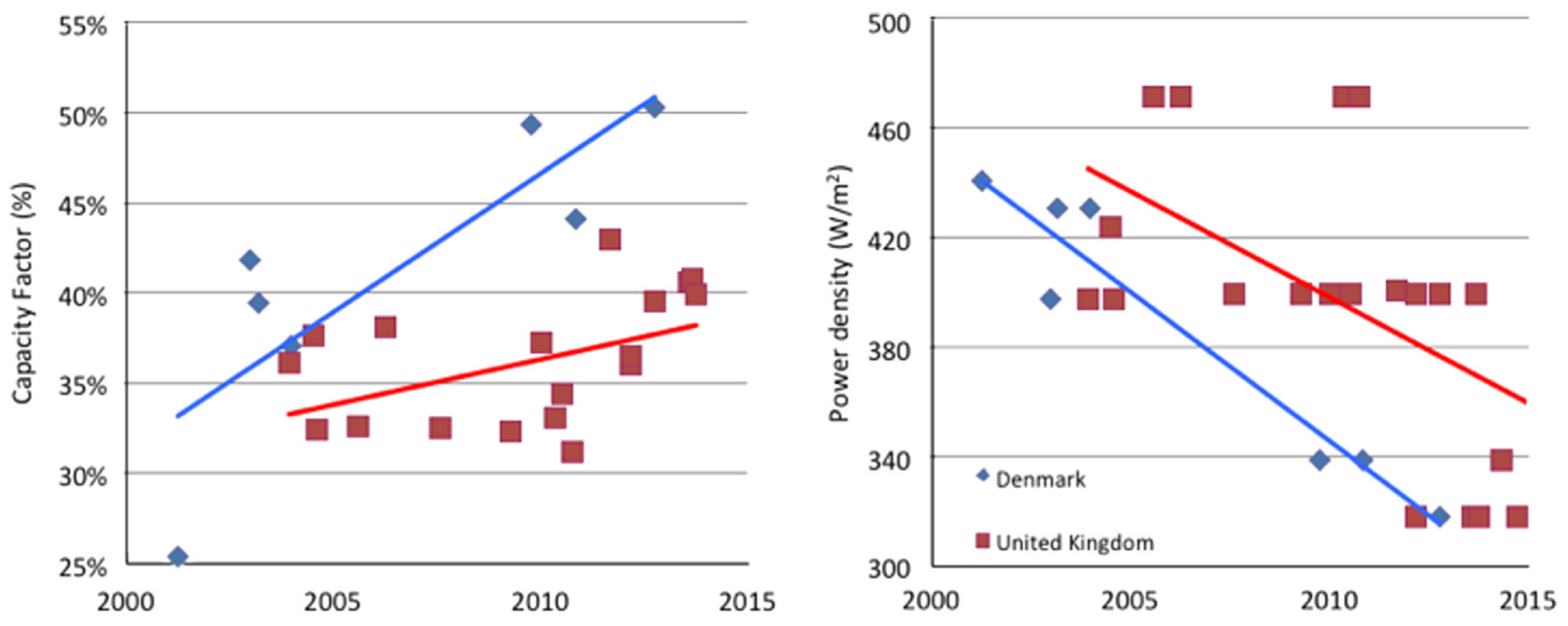

Fig. 8. Capacity factor (left) and power density (right) of OWF's in the UK and Denmark.

capacity factor even up to $50 \%$ for the most recent OWF. This difference does not seem to be a result of higher wind speeds but appears to be a result of the applied technology. For UK projects, realization time in some cases took about 10-13 years. Therefore, it has not been possible to incorporate new technologies into these OWFs. In Denmark, the project realization time is much shorter, generally 4 years.

Based on our analysis, we suggest that the two following issues require additional policy attention. As technology is rapidly evolving, it is key to minimize the project realization time of OWFs, allowing projects to use state-of-the-art technology. In case of delays, which occur frequently for OWF's, policies should be flexible allowing the technology to be updated if improved products or services have become commercially viable. The 'Rochdale envelope' introduced in the UK is an example of achieving this, and we recommend that this principle is also applied in other countries where offshore wind farms are developed. Secondly, unstable or unpredictable policy frameworks have a big impact on the financing costs. This research indicates a stable framework such as in Denmark can result in a $22 \%$ lower LCoE compared to an uncertain framework such as in the UK due to a lower WACC. Therefore, it is important that the policy framework provides certainty regarding the annual income for a project during its entire lifetime. There are several actions policymakers could take to increase consistency and stability of the policy framework. First, by simplifying the application process, where all the required permits are granted simultaneously (already applied in Denmark). Second, by providing stable, long-term growth perspectives, and finally by reducing the variability of the financial support an OWF can receive during its operational lifetime.

Last but not least, we want to emphasize that the tripling of the CAPEX and the doubling of the LCoE in the past 15 years only represents the worst (UK) case. In the Danish case, CAPEX increased more moderately, and LCoE in fact remained more or less constant. Also, around 2012, the general increase of both CAPEX and LCoE has stopped and slowly started to decrease. Industry has also committed to work hard on further cost reductions. If this trend can continue due to further improving of technology and the political framework, offshore wind energy is likely to have a bright future.

\section{Acknowledgements}

The authors would like to thank the following persons who work at TKI-WoZ for allowing us to use the cost model and providing feedback and useful insights during this research: Ernst van Zuijlen, Arjan Mast, Bob Meijer and Michiel Zaaijer. Also Bob Prinsen (Ecofys) and Roberto Lacal Arántegui (JRC) are gratefully acknowledged for their helpful advice.

\section{References}

Accenture, 2013. Changing the Scale of Offshore Wind, Examining Mega-projects in the United Kingdom. Accenture.

Barthelmie, R., Pryor, S., Frandsen, S., Hansen, K., Schepers, J., Rados, K., Schlez, W., Neubert, A., Jensen, L., Neckelmann, S., 2010. Quantifying the impact of wind turbine wakes on power output at Offshore Wind Farms. J. Atmos. Ocean Technol. 27, 1302-1317.

Belwind, 2014. Belwind Website: Planning and Timeline. Available at: 〈http://www. dongenergy.co.uk/Documents/UK\%200ffshore\%20Wind\%20Farm\% 20Development\%20Process.pdf $\rangle$ (accessed January 2015).

Boston Consulting Group, 1968. Perspectives on Experience. Boston Consulting Group Inc..

Boughton, J.M., Branson, W.H., 1988. Commodity Prices as a Leading Indicator of Inflation. The National Bureau of Economic Research. Cambridge University Press, New York.

BVG, 2012. Offshore Wind Cost Reduction Pathways, Technology Work Stream. Renewable UK.

CEPA, 2011. Note on Impact of the CFD FIT Support Package on Costs and Availability of Capital and Existing Discounts in Power Purchase Agreements. Cambridge Economic Policy Associates ltd (accessed January 2015).

De Vries, E, 2011. Close up - the Vestas V164 7 MW Offshore Turbine. WindPowerMonthly.com Available at: 〈http://www.windpowermonthly.com/article/ 1065676/close-vestas-v164-7mw-offshore-turbine (accessed January 2015).

Dong Energy, 2013. A view on the steel demand for offshore wind power. Dong Energy (accessed March 2015) 〈http://www.platts.com/IM.Platts.Content/Pro ductsServices/ConferenceandEvents/2013/gc397/presentations/Nikolaj_Ager_ Hamann.pdf).

Dong Energy, 2014. Offshore wind cost of electricity information package. Available online: 〈http://assets.dongenergy.com/DONGEnergyDocuments/com/Business\% 20Activities/Wind\%20Power/Cost\%20of\%20energy_presentation_EN.pdf $)$.

ECB, 2015. Measuring Inflation in the Euro Areas: the Harmonised Index of Consumer Prices (HICP). Available at: 〈https://www.ecb.europa.eu/stats/prices/ hicp/html/inflation.en.html (accessed April 2015).

Energynumbers.info, 2014. Capacity factors as Danish Offshore Wind Farms. Available at: 〈http://energynumbers.info/capacity-factors-at-danish-offshorewind-farms $>$ (accessed March 2015).

European Wind Energy Technology Platform. Strategic Research Agenda Market Development Strategy. Available at: 〈http://www.windplatform.eu/fileadmin/ ewetp_docs/Documents/reports/TPWind_SRA.pdf (accessed April 2015).

EWEA, 2011A. Pure Power - Wind Energy Targets for 2020 and 2030. The European Wind Energy Association.

EWEA, 2013. Where's the Money Coming From? Financing Offshore Wind Farms. The European Wind Energy Association.

EWEA, 2014. Wind Energy Scenarios for 2020. The European Wind Energy Association.

EWEA, 2015. The European Offshore Wind Industry Key Trends and Statistics 2014. The European Wind Energy Association.

Fichter, Prognos, 2013. Cost Reduction Potentials of Offshore Wind Power in Germany. The Fichtner Group and Prognos AG. 
FLOW, 2014. Far and Large Offshore Wind, General Website. Available at: 〈http:// flow-offshore.nl/> (accessed April 2015).

FLOW, 2015. FLOW Offshore Wind Cost Model, Modelling the Cost of Offshore Wind Energy in the Netherlands. Available at: 〈http://flow-offshore.nl/page/flow-off shore-wind-cost-model $>$ (accessed April 2015).

Fraunhofer, 2013. Levelized Cost of Electricity Renewable Energy Technologies. Fraunhofer Institute for solar energy systems ISE, Freiburg, Germany.

Granheim, O., Olsen, B., Madsen, E.S., 2012. Kriegers Flak: How Will Policy, Law and Financing Affects a Combined Solution Project?. Aarhus University, Aarhus, Denmark.

Green Giraffe. Impact of Financial Crisis on Cost of Wind Energy, Presentation at EWEA Conference Vienna; 2013.

GWEC, 2014. Global Wind Energy Outlook 2014. Global Wind Energy Council.

IEA, 2014. How 2 Guide for Wind Energy, Roadmap Development and Implementation. International Energy Agency.

IEA Wind, 2015. Task 26 Cost of Wind Energy, 〈http://www.ieawind.org/task_26. html $>$ (accessed April 2015).

INNWIND, 2014. Key Performance Indicators \& Target Values for Multi-MW Offshore Turbines. Presentation at EWEA 2014, Barcelona. Available at: 〈http://or bit.dtu.dk/ws/files/90239891/Key_Performance_Indicators_presentation.pdf (accessed April 2015).

IMF, 2012. Commodities in boom. Int. Monet Funds, Financ. Dev. 49 (2), 30-31.

IPC, 2011. Using the 'Rochdale Envelope', Infrastructure Planning Commission. Bristol. United Kingdom. Available at: 〈http://infrastructure.independent.gov. uk/wp-content/uploads/2011/02/Advice-note-9.-Rochdale-envelope-web.pdf) (accessed January 2015)

IRENA, 2012. Renewable Energy Technologies: Cost Analysis Series, Wind Power. International Renewable Energy Agency.

IRENA, 2015. Renewable Power Generation Costs in 2014. International Renewable Energy Agency, Available at: 〈http://www.irena.org/menu/index.aspx? $\mathrm{mnu}=$ Subcat $\&$ PriMenuID $=36 \&$ CatID $=141 \&$ SubcatID $=494\rangle$.

JRC, 2014. 2013 JRC Wind Status Report, Technology, Market and Economic Aspects of Wind Energy in Europe. Joint Research Centre, Petten, The Netherlands, Available at: 〈https://ec.europa.eu/jrc/sites/default/files/ldna26266enc_2013 jrc_wind_status_report_final.pdf?search $\rangle$.

Junginger, M., Faaij, A., Turkenburg, W., 2005. Global experience curves for wind farms. Energy Policy 33, 133-150.

Junginger, M., Faaij, A., Van Sark, W., 2010. Technological Learning in the Energy Sector, Lessons for Policy, Industry and Science. Edward Elgar Publishing, Cheltenham, UK, p. 2010.

Kaiser, M.J., Snyder, B, 2010. Offshore Wind Energy Installation and Decommissioning Costs Estimation in the U.S. Outer Continental Shelf. Available at: 〈http://www.fairtran.com/images/OffshoreEstimation.pdf (accessed January 2015)

Klaassen, G., Miketa, A., Larsen, K., Sundqvist, T., 2005. The impact of R\&D on innovation for wind energy in Denmark, Germany and the United Kingdom. Ecol. Econ. 54, 227-240.

Lacal Arántegui, R., 2014, Scientific Officer at JRC, Personal Communication. 19th of November 2014

Levitt, A.C., Kempton, W., Smith, A., Musial, W., Firestone, J., 2011. Pricing offshore wind power. Energy Policy, Sustain. Biofuels 39 (10), 6408-6421.

MacGillivray, A., Jeffrey, H., Winskel, M., Bryden, I., 2014. Innovation and cost reduction for marine renewable energy: a learning investment sensitivity analysis. Technol. Forecast. Soc. Chang. 87, 108-124.

Möller, B., Hong, L., Lonsing, R., Hvelplund, F., 2012. Evaluations of offshore wind resources by scale of development. Energy 48 (1), 314-322.

Navigant, 2014. Offshore Wind Market and Economic Analysis. Available at: 〈http:// energy.gov/sites/prod/files/2014/08/f18/2014\%20Navigant\%200ffshore\% 20Wind\%20Market\%20\%26\%20Economic\%20Analysis.pdf $>$ (accessed in January 2015).

NREL, 2010. Large-Scale Offshore Wind Power in the United States, Assessment of
Opportunities and Barriers. National Renewable Energy Laboratory.

ORE Catapult, 2015. Cost reduction monitoring framework, summary report to the offshore wind programme board. Offshore Renew. Energy Catapult, Available at: 〈https://ore.catapult.org.uk/documents/10619/110659/ORE\%20Catapult\% 20report\%20to\%20the\%200WPB/a8c73f4e-ba84-493c-8562-acc87b0c2d76 .

Perveen, R., Kishor, N., Mohanty, S., 2014. Offshore wind farm development: present status and challenges. Renew. Sustain. Energy Rev. 29, 780-792.

Prässler, T., Schaechtele, J., 2012. Comparison of the financial attractiveness among prospective offshore wind parks in selected European countries. Energy Policy 45, 86-101.

Prinsen, B., 2014, Wind energy consultant Ecofys. Personal Communication. 5th November 2014.

Rabobank, 2011. Offshore Wind: Foundations for Growth. Rabobank International and Bloomberg New Energy Finance, Utrecht.

RenewableUK, 2014a. Offshore Wind Project Timelines 2014. RenewableUK, London, United Kingdom.

RenewableUK, 2014b. Development Rounds Offshore Wind Energy. Renewable UK, London, United Kingdom. Available at: 〈http://www.renewableuk.com/en/re newable-energy/wind-energy/offshore-wind/development-rounds.cfm〉 (accessed January 2015)

Rijksoverheid, 2011. Greendeal van Nederlandse Wind Energie Associatie met de Rijksoverheid. Available at: 〈http://nwea.nl/sites/default/files/Green\%20Deal\% 200ffshore\%20Windenergie\%20oktober\%2011\%20(scan).doc.pdf), (accessed October 2014).

SETIS, 2011. Key Performance Indicators for the European Wind Industrial Initiative Strategic Energy Technology Information.

Siemens, 2013. Wind Power on its Way to Cost Reduction (press release). Available at: 〈http://www.siemens.com/press/en/pressrelease/?press=/en/pressrelease/ 2013/energy/wind-power/ewp201311010.htm>.

The Crown Estate, 2012. Offshore Wind Cost reduction, Pathways study. The Crown Estate.

The Economist, 2014. Oil and trouble, tumbling resource prices suggest the world economy is slowing. The Economist Finance and Economy. Available at: $\langle$ http:/ www.economist.com/news/finance-and-economics/21621875-tumbling-re source-prices-suggest-world-economy-slowing-oil-and-trouble $>$ (accessed April 2015).

TKI-WoZ, 2015. Top consortium for Knowledge and Innovation Offshore wind. Available at: 〈www.tki-windopzee.eu $\rangle$ (accessed March 2015).

UKERC, 2010. Great Expectations: The Costs of Offshore Wind in UK Waters Understanding the Past and Projecting the Future. United Kingdom Energy Research Centre.

Variablepitch, 2015. Available at: 〈http://www.variablepitch.co.uk/category/off_ shore_wind/> (accessed March 2015).

Van der Zwaan, B., Rivera-Tinoco, R., Lensink, S., Oosterkamp, P., 2012. Cost reductions for offshore wind power: Exploring the balance between scaling, learning and R\&D. Renew. Energy 41, 389-393.

Windpowermonthly, 2012. Wind Turbine Prices Could Fall Until 2014. Available at: 〈http://www.windpowermonthly.com/article/1117015/turbine-prices-fall-until2014) (accessed January 2015).

Windpowermonthly, 2015. EWEA Offshore: Though Competition Behind Horns Rev 3 tender. Windpowermonthly. Available at: 〈http://www.windpowermonthly. com/article/1337435/ewea-offshore-tough-competition-behind-horns-rev-3tender $\rangle$.

World Energy Council, 2013. World Energy Perspective Cost of Energy Technologies. World energy Council and Bloomberg New Energy Finance, Available at: 〈http://www.worldenergy.org/wp-content/uploads/2013/09/WEC_J1143_Costof TECHNOLOGIES_021013_WEB_Final.pdf $\rangle$.

Zaaijer, M., 2014. Assistant Professor TUDeflt, Personal Communication. 17th of December 2014.

3E, 2013. Benchmarking Study on Offshore Wind Incentives, Comparison of the Systems in 6 Neighbouring Countries. 